Uniwersytet Marii Curie-Skłodowskiej w Lublinie

Wydział Humanistyczny

Instytut Filologii Słowiańskiej

tel.: +48815372627

e-mail: ewa-stawinoga@wp.pl

\title{
Dramat poety, czyli Borysa Popławskiego ,zmagania z Bogiem”
}

Słowa kluczowe: Borys Popławski, pierwsza fala emigracji, Bóg, kryzys duchowy

W tytule referatu użyto sformułowania „zmagania z Bogiem”, gdyby jednak chcieć dokładnie trzymać się wersji oryginału, należałoby powiedzieć: „romans z Bogiem” („роман с Богом”). Ta „niewielka korekta” słów rosyjskiego poety zasadniczo nie zmienia tego, co pod nimi się kryje, a oddaje wewnętrzny dramat, jaki całe życie rozgrywał się w jego duszy.

„Роман с Богом" - to formuła w naturalny sposób wyrażająca poszukiwanie Boga; naczelna idea, której Popławski, podporządkował całe swoje życie, co poświadcza najbliższy przyjaciel - Nikołaj Tatiszczew ${ }^{1}$; to wreszcie główny temat jego dzienników, twórczości poetyckiej i prozatorskiej, stanowiącej, zdaniem Dmitrija Tokariewa, fragment „той «переписки с Богом», которую Поплавский вел на протяжении своей жизни" [Токарев 2011, 117].

Niniejsze rozważania chcielibyśmy jednak rozpocząć od przybliżenia duchowej sylwetki autora Wierszy automatycznych. Już na samym początku należy podkreślić, że jego stosunek do Boga i religii jest daleki, a chwilami

1 „Главную, единственную тему своей жизни Поплавский называл «романом с Богом»" [Татищев 1993, 92]. 
nawet sprzeczny z oficjalną nauką Kościoła. Z tego względu, podobnie jak Lermontowa czy Sołoguba, można go zaliczyć w poczet bogoburców. Mamy tu jednak na myśli takie znaczenie tego terminu, w jakim został użyty przez Dmitrija Mierieżkowskiego; chodzi tu mianowicie о „святое богоборчество” [Мережковский, online], czyli o walkę z Bogiem, ale nie przeciwko Niemu, nie odrzucenie i nie zaprzeczenie Jego istnieniu. Analizując twórczą biografię Lermontowa przywódca rosyjskiego symbolizmu dochodzi bowiem do wniosku, że wiodąc spór z Bogiem² był on bliżej Niego, niż ci, co pozostawali wobec Boga obojętni: „Никто никогда не говорил о Боге с такою личною обидою, как Лермонтов (...). Никто никогда не обращался к Богу с таким спокойным вызывом (...). Никто никогда не благодарил Бога с такою горькою усмешкою" [Мережковский, online].

Sam Popławski w jednym z listów do Ilii Zdaniewicza przyznawał, że jest chrześcijaninem: „Да, я христианин, хотя Вам кажусь лишь подлецом, с позором покидающим «храбрый народец»" [Поплавский 2009k, 469]. Uważał się ponadto za osobę głęboko wierzącą, regularnie chodził do cerkwi, zwłaszcza po emigracji z Rosji, co dawało mu poczucie wspólnotowości i przynależności do utraconej ojczyzny i tradycyjnych wartości. Jak pisze Hélène Menegaldo, „для разъединенного общества церковь являлась местом общения: обеспечивая постоянство традиции, она предоставляла возможность сохранить чувство национального единства" [Менегальдо 2007, 220]. Ten stan rzeczy nie trwał długo. Poeta stopniowo oddalał się od Cerkwi, twierdząc, że jest zbyt zinstytucjonalizowana i podlega władzy świeckiej, a co za tym idzie utraciła swoją pierwotną duchowość. Wzorem religijności pozostawali dla niego pustelnicy, asceci, tzw. „starcy" 3 oraz biedni i w pełni oddani modlitwie kapłani:

(...) официальной, исторической церкви Поплавский противопоставлял Церковь идеальную, которая воплощала бы дух православия. Эта иная Церковь, в сущности, уже имеется вне всяких иерархий и догм. Эта Церковь - бедные деревенские священники, странники, старцы, святые люди, бессчисленная масса преданных вере, воплощенной в них ${ }^{4}[$ Менегальдо 2007, 223].

2 Por. słowa Bierdiajewa: „Богу совсем не нужны покорные и послушные рабы, вечно трепещущие и эгоистически занятые собой. Богу нужны сыны, свободные и творящие, любящие и дерзновенные" [Бердяев 1926, 37].

3 Starcami w tradycji prawosławnej nazywa się mnichów nieposiadających święceń kapłańskich.

4 Sam poeta w jednej ze swoich recenzji pisze: „Что такое православие? - Это нищая религия. Неизвестная и неизданная мистическая поэзия, разоренные храмы, смиренные священники" [Поплавский 2009d, 84]. 
W Cerkwi przeszkadzał mu ponadto formalizm, czyli wszelkiego rodzaju obrzędy, uniemożliwiające, jego zdaniem, bezpośredni, osobisty kontakt z Bogiem. Popławski stał bowiem na stanowisku, że człowiek powinien dążyć do spotkania z Bogiem w sposób indywidualny, bez żadnych pośredników - kapłanów, czy przewodników duchowych, których uważał za przeszkodę w budowaniu tego rodzaju relacji ${ }^{5}$. Można zatem rzec, że reprezentował ten typ chrześcijaństwa, który Nikołaj Bierdiajew nazywał „nowym”, twórczym i przeciwstawiał chrześcijaństwu ortodoksyjnemu, konserwatywnemu ${ }^{6}$ [Бердяев 1932, 17]. Twórcze chrześcijaństwo, zdaniem rosyjskiego filozofa, zakłada aktywność zarówno obiektu religijnego (Boga), jak i podmiotu (człowieka). A zatem wiara nie sprowadza się tu tylko do przedmiotowego bycia we wspólnocie, nie jest dana z góry, narzucona przez normy i społeczność, w jakiej wyrośliśmy ${ }^{7}$, lecz ma charakter podmiotowy. W relacji z Bogiem istotne jest osobowe przeżycie (a więc bez pośrednictwa instytucji) oraz oryginalne (tzn. odsyłające do źródła) doświadczenie duchowe i intuicja, które Bierdiajew definiuje jako „прорыв к первоисточнику, (...) стояние перед Богом, перед тайной бытия без социального опосредствования" [Бердяев 1932, 22-23].

Łada Syrowatko światopogląd Popławskiego określa z kolei mianem „,nowego chrześcijaństwa" [Сыроватко 2004, 165], gdyż poeta praktykował nie tylko prawosławie, ale należał również do członków Towarzystwa Teozoficznego, ezoterycznego Zakonu Gwiazda Wschodu; nieobcy mu był także mistycyzm, gnostycyzm ${ }^{8}$, a nawet okultyzm [Zob. Поплавский 2009e, 212]. Niewątpliwy wpływ na jego duchowe poszukiwania wywarła atmosfera domu rodzinnego, a zwłaszcza zainteresowania matki - dalekiej krewnej Heleny Bławackiej oraz zwolenniczki ideologii Rudolfa Steinera. Do obowiązkowych lektur młodego twórcy zaliczyć należy Kabałe, prace wspomnianego Steinera, Bławackiej, Krishnamurti, Leadbeatera, Böhmego, Nietzschego,

5 Jest to bez wątpienia wpływ mistycyzmu, którym Popławski się interesował. „Mistycy - pisze Radosław Czarnecki (...) przeczą zasadności egzystencji „pośredników” (instytucjom, biurokracji, hierarchii) kontaktu indywiduum z najwyższym sacrum" [Czarnecki, online].

6 Kwestię tę szczegółowo omawia Maria Cymborska-Leboda [Zob. Cymborska-Leboda 2014, 497-511].

7 Por. „(...) вера слишком часто объясняется социологической зависимостью, она не оказывается чистым стоянием религиозного субъекта перед религиозным объектом" [Бердяев 1932, 23].

8 Dmitrij Tokariew w monografii poświęconej Popławskiemu pisze, że najbardziej prawdopodobnym źródłem wiedzy poety o gnostycyzmie była książka Eugène de Faye - Gnostiques et gnosticisme. Etude critique des documents du gnosticisme chrétien aux IIe et IIIe stècles, Paris 1925. [Zob. Токарев 2011, 227]. 
Schopenhauera, Hegla, Kanta, Bergsona, czy wreszcie św. Jana od Krzyża, św. Teresy z Ávila, św. Teresy z Lisieux (od Dzieciatka Jezus), itp. ${ }^{9}$

Wymienione wyżej systemy religijne i poglądy miały wskazać poecie droge do upragnionego, fizycznego kontaktu z Bogiem, zjednoczenia się z Nim ${ }^{10}$. Wykorzystywał on w tym celu również ascezę, medytacje, narkotyki oraz modlitwy. Nie wystarczało mu bowiem zapewnienie, dogmat o istnieniu Boga; podobnie, jak św. Tomasz, chciał Go dotknąć, obcować z Nim w sposób bezpośredni, namacalny. Pragnął tej bliskości i pełni miłości, jakich nie otrzymał od najbliższych - matki, ukochanej kobiety, przyjaciół. Czy nie z tego właśnie powodu relację łączącą człowieka (duszę) i Boga określa mianem „romansu”, sprowadzając ją do aktu seksualnego (zjednoczenia płciowego - совокупление)? ${ }^{11}$. Naszym zdaniem, to wynik głębokich studiów mistycznych ${ }^{12}$ oraz ezoterycznych; tego rodzaju paralele obecne są przecież w ramach wymienionego typu myślenia, na przykład w mistyce oblubieńczej [Zob. Kłoczowski 2003, 99-112; 219-241]. Już w starotestamentowej

9 Dokładny spis tego, co poeta czytał odnajdujemy na kartach jego dzienników [Zob. Поплавский 2009е, 153-250].

10 Władimir Warszawski podkreśla, że Popławski nie tylko marzył o bezpośrednim, fizycznym spotkaniu z Bogiem, ale też głęboko wierzył w taką możliwość [Zob. Варшавский 1993, 57].

11 „(...) монастырь, молитва и особенно келья и есть альков для совокупления с самим Богом, причем Бог всегда мужчина, а душа - женщина, раскрывающаяся, поднимающаяся горбом к Богу, Белусу, солнцу, Создателю мира ..." [Поплавский 2009b, 378]. W innym miejscu zaś pisze: „Святость есть никому не необъяснимые личные отношения с Богом, наподобие супружеской любви, в «качество» которой никто извне проникнуть не может, а извне «что они делают, душа с Богом или муж с женой?»- «Да все то же самое»” i dalej: „(...) ибо я знаю, что у каждого, абсолютно каждого есть свой неповторимый личный заговор с Богом, свои физические, сексуальные отношения с ним (...)" [Поплавский 2009f, 122, 132]. W dziennikach zaś czytamy: „(..) человек был сотворен как жена Бога, однако Бог захотел испытать ее верность, дать ей возможность свободно определить себя к нему, и поэтому он отдалися от нее, прекратил с ней непрестанное до того половое сердечное общение. И тогда Люцифер ее научил изменить Богу с ним, воспользоваться совокуплением не для утверждения жизни, а для наслаждения ею" [Б. Поплавский 2009g, 320].

12 Por.: „Мистики используют множество образов и символов, а также особых выражений и форм специальной речи, пытаясь выразить с помощью языка то, что лежит за его пределами. Эротические любовные образы - поцелуй, объятие, воспоминание о встрече, даже сексуальный контакт, - являются предпочтительными способами выражения мистического союза” [Макгинн, online]. Podobną myśl odnajdujemy w tekście znanego rosyjskiego kompozytora Aleksandra Skriabina: „Quand [le Dieu-personne] atteint le plus haut niveau de la montée, et ce temps approche, il communiquera sa béatitude à tout l'organisme. Comme l'homme au moment de l'acte sexuel, dans la minute de l'extase perd conscience, et tout son organisme dans tous ses points vit la béatitude, anisi le Dieu-homme, en vivant l'extase, remplira l'univers de beatitude et allumera l'incendie" [Scriabine 1979]. 
Pieśni nad pieśniami odnajdujemy porównanie uczucia kochanków do relacji duszy z Bogiem, zaś w tekstach średniowiecznych mistyków, a zwłaszcza mistyczek - pisze ojciec Jan Andrzej Kłoczowski, nabierają one charakteru sensytywnego, by nie powiedzieć erotycznego (np. u św. Katarzyny ze Sieny, czy Mechtyldy z Magdeburga) [Por. Kłoczowski 2003, 228]. To również dramatyczne wołanie osamotnionego i nieszczęśliwego człowieka, marzącego o miłości i intymnej więzi, a także, jak się wydaje, próba zwrócenia na siebie uwagi ${ }^{13}$. Popławski (jak sam o sobie myślał), to bowiem typ zakompleksionego, zamkniętego w sobie nadwrażliwca, chowającego się za czarnymi okularami, a jednocześnie muskularny bokser, który dla uciechy tłumu urządza dzikie awantury, upija się, a swoim oczytaniem i elokwencją przyćmiewa największe gwiazdy paryskiej bohemy. U znawczyni twórczości „rosyjskiego Rimbaud" - Hélène Menegaldo rodzą się w związku z tym wątpliwości. Francuska badaczka stawia pytanie, czy w przypadku Popławskiego nie mamy aby do czynienia z „pozą świętości”? [Zob. Менегальдо 2007, 254].

Poeta poświęcał Bogu i modlitwie bardzo wiele czasu, o czym świadczą chociażby jego zapisy w dziennikach:

\subsubsection{1}

Рано утром молился, в 12 в маленький французский ресторан. Молился опять. В театре. Ресторан. Рисовал. Большая радость. Вечером молился 3 раза.

26.8 .21

Утром рисовал Сахарова. Зубной врач ... Домой ... Обедал в маленьком ресторанчике. Молился 2 раза (...).

27.8.21

Папа уезжает, складывали вещи, был у баронессы. Рисовал папу и побежал за такси. Поехали, молился перед отходом в разгромленой комнате. Прощались с баронессой. Домой, молился ${ }^{14}$ [Поплавский 2009е, 198].

Jednak, jak sam przyznawał, jego rozmowy z Bogiem były puste, pozbawione łaski: „(...) медитировал на мокрых улицах и дома. Отсутствие благодати. Молитва впустую" [Поплавский 2009c, 430-431]; w innym miejscu: „Долгая бесплодная молитва, наполовину наяву, наполовину во сне (...)" [Поплавский 2009c, 445]. Modlitwa zaś to łaska, możliwość dialogu z Bogiem, przy czym, jak podkreśla biskup Jan Szkodoń, człowiek sam z siebie nie potrafi się modlić. Potrzeba działania Ducha Świętego, który

13 Por. „Поплавский не любил пребывать незамеченным или же быть безразличным для других. Ему всегда необходимо привлекать внимание, покорять, обольщать, внушать восторг - словом, торжествовать (...)" [Менегальдо 2007, 186].

14 Tu i w dalszej części tekstu wyróżnienia moje - E. S. 
uzdolni nas do tego, aby z Bogiem rozmawiać [Zob. Szkodoń 2003, 151]. Popławskiego tymczasem interesowała przede wszystkim technika, pozwalająca mu zrealizować spotkanie z Bogiem. W tym celu studiował pisma hinduskich mistrzów oraz chrześcijańskich mistyków. Jednak ani asceza, ani próby wprowadzenia się w stan ekstazy przy pomocy praktyk kontemplacyjnych i narkotyków nie przyniosły zamierzonego efektu. W prawdziwie chrześcijańskiej modlitwie nie chodzi bowiem o metody - pisze Ojciec Grzegorz Ginter, gdyż wówczas staje się ona pustą techniką. „Najważniejsze - kontynuuje znany jezuita - jest być z Jezusem, tak jak zakochani są ze sobą i często komunikują się bez słów. To zdanie sobie sprawy, że tak często wystarczy tylko kochające spojrzenie - moje na Boga i Boga na mnie, tak jak zakochanym wystarczy patrzeć na siebie" [Ginter, online]. Popławski zaś traktował modlitwę tak, jak swoje ćwiczenia z hantlami; przyrównywał ją zresztą do gimnastyki [Zob. Поплавский 2009c, 435]. Nie chodziło w niej o wielbienie Boga ${ }^{15}$, tylko o bezlitosną tresurę ciała; no bo jak nazwać wielogodzinne wyczerpujące medytacje, wywołujące krwotoki? ${ }^{16}$ To wszystko, jak również chęć upodobnienia się do swoich ulubionych mistyków i Chrystusa, poprzez świadomy wybór życia w ubóstwie, rodzi wrażenie, że poeta pragnął przykuć uwagę Stwórcy [Zob. Менегальдо 2007, 215], podobnie jak awanturniczym trybem życia chciał zapewnić sobie atrakcyjność wśród znajomych i przyjaciół. Jego próby kontaktu, komunii z Bogiem, z góry skazane były na niepowodzenie, dlatego że miały jedynie charakter zewnętrzny (, Внешний аскетизм" [Менегальдо 2007, 252]). Nikołaj Bierdiajew w związku z tym powie, iż największe nieszczęście Popławskiego tkwiło w tym, że nie poszukiwał prawdy, tylko czegoś niezwykłego, nadprzyrodzonego [Zob. Бepдяев 2010, 14]. „Святость - pisze rosyjski myśliciel - для него была прежде всего необыкновенностью, она должна была увести его от реальности, с которой он никак не мог привести себя в соответствие" [Бердяев 2010, 9].

15 Por. „(...) każda dobra modlitwa zawiera w sobie wyraźnie lub pośrednio akt poddania się najwyższemu Panu. Prócz tego modlitwa udoskonala wszystkie te akty, gdyż na niej korzymy się przed Boskim Majestatem, by Go wielbić i błagać o nowe łaski, konieczne do dalszego postępu w doskonałości" [Tanquerey 2003, 288].

16 Badaczka twórczości Popławskiego pisze: „Поплавский ежедневно молился, воспринимая молитву как аскезу, о чем свидетельствует его дневник. Любопытно, что это походило у него на некое спортивное занятие; суть заключалась в том, чтобы упражнения доходили до самого предела сил, одним словом - побивали прежний рекорд. В юношеские годы он приучился молиться несколько часов кряду, что вызывало состояние чрезмерной слабости и, как следствие, шум в ушах и кровотечение из носа" [Менегальдо 2007, 249]. 
Prawdziwy dramat poety rozpoczął się jednak wówczas, gdy do upragnionego mistycznego miłosnego połączenia nie doszło - „бесконечные молитвы без ответа” [Поплавский 2009c, 439] / „Невроз, невроз и невроз. Раскаленные дни, лицом к лицу с Богом и с дьяволом в молчани Бога (...)" [Поплавский 2009c, 442]. Nieudana próba zdobycia nieba, czyli nieurzeczywistniony „romans” oraz związany z tym bolesny powrót na ziemię (домой с небес ${ }^{17}$ ) wywołują u Popławskiego duchowy kryzys. Zniecierpliwiony ${ }^{18}$ i zawiedziony ${ }^{19}$ poeta, zamiast pogłębić swoją relację z Bogiem, obraża się na Niego ${ }^{20}$ і czyni Mu wymówki: „кто знает, сколько мне Бог уже стоил, сколько я уже лишился из-за Бога, чтобы под конец и лишиться Бога" [Поплавский 2009h, 309]. Za chwilę zaś znów Go przyzywa, prosząc о pomoc: „Господи, помоги умирающему” [Поплавский 2009e, 234]. Używając erotycznej semantyki, jaką w odniesieniu do relacji ze Stwórcą stosuje autor Флагов, można by rzec, że jego kontakty z Bogiem sprowadzały się do ciągłych „zdrad” i powrotów, które odzwierciedlały wewnętrzny konflikt, toczony w jego duszy. Praktykowany przez Popławskiego synkretyzm religijny nie tylko go wzmagał, ale i stopniowo wypaczał prawdziwy obraz Boga oraz chrześcijański ideał świętości. Bóg dotychczasowy obiekt pożądania i tęsknoty przybrał z czasem oblicze złego demiurga, pozbawionego miłosierdzia i współczucia sędziego, który, obdarzywszy człowieka niewyobrażalnie ciężkim darem wolności i odpowiedzialności, skrywa się z powrotem w niebiosach, zostawiając swoje stworzenie na pastwę losu w złowrogiej, pełnej niebezpieczeństw i pokus materialnej rzeczywistości:

Страшный, ужасающий, холодный, яркий мир вокруг: все как будто сделано из железа, из замерзшего кала, все выдумано, вылеплено назло. Каждое уродство - живой, ходячий, бесполезный упрек мне... и Богу [Поплавский 2009c, 439].

\footnotetext{
17 To jednocześnie tytuł drugiej powieści Popławskiego.

18 Por. „Это конвульсивное стремление к святости соседствует с великой нетерпеливостью, которая выявляется у Поплавского на каждой странице дневника: он жаждет святости теперь же или никогда и раздражается, что милость Божья медлит явится" [Менегальдо 2007, 256].

19 Por. „(...) он испытывает постоянное разочарование. Он хотел бы достигнуть экстаза. Не достигая экстаза, он Бежит от Бога и потом опять возвращается к Богу" [Бердяев 2010, 10].

20, „...) темные, долгие, упорные молитвы без толку, однообразная жвачка, упрек Богу, обида на Него. Может быть, возврат к очевидности греха" [Поплавский 2009c, 439].
} 
Co więcej: poeta - i nie on pierwszy - uważał, że to właśnie Bóg, a nie człowiek jest odpowiedzialny za zło i jego rozprzestrzenienie się; oskarża Go ${ }^{21}$ o to, iż poprzez swój egoistyczny akt stwórczy naruszył pierwotną jedność i tym samym zainicjował grzech. Należy jednak podkreślić, iż Popławski, obciążony tradycją mistyczną spod znaku Bławackiej, wyraźnie mitologizuje postać Boga i rozpatruje go w kontekście innych ekstatycznych bóstw mitologicznych, o czym może świadczyć poniższy fragment dziennika, w którym wspominany akt twórczy przyrównywany jest do aktu ekstazy:

(...) Христос плакал, он плакал от стыда за Творение, за Бога, который, опьяненный любовью, как Парис на пиру богов, опьяненный амброзией при рождении Афродиты, не учтя мук, закрыв глаза на муки, сказал: «Да будет свет», - и свет отделился от тьмы, разрушив первичное спокойное небытие $^{22}$ [Поплавский 2009i, 345].

Przez to niewątpliwe obwinienie, skierowane pod adresem Najwyższego, prześwieca jednak inna pierwotna prawda, którą poecie podsuwa głęboka mistyczna intuicja, mianowicie, że Bóg stworzył świat z nadmiaru miłości do człowieka - „опьяненный любовью” 23 . Mimo to, w innym miejscu swojego dziennika pysznie twierdzi, że byłby o wiele lepszym stwórcą, a jego dzieło okazałoby się na pewno piękniejsze:

Я наверное сделал бы вселенную гораздо красивее и удобнее, чем Бог. Звезды напр. сделал бы всех цветов. Деревья с синими, фиолетовыми и шоколадными листьями а также с членами и влагалищами, человека сделал бы с крыльями и т. д. Вселенная не остроумна и не корректна. Земля скучна и неприлична и все это пахнет неудачей, дилетантством, неврастенией и спешкой (...) [Поплавский 1927, online].

Pisarz, w ślad za swoimi gnostyckimi mentorami (Marcjonem, Bławacką), odrzuca Boga na niebiosach, uważając Go za zwykły wymysł; oddziela

21 „(...) что я могу сказать против Бога? Да, против, ибо мука мира глубока” [Поплавский 2009c, 431].

22 W innym miejscu swego dziennika Popławski pisze: „Бог кажется мне неудачником, мучеником своей любви, которая, подобно похоти, заставляет его, вынуждает твореить" [Поплавский 2009c, 431].

23 Por. „When we see what Christ's very nature is cruciform - that the exhilarating joy of Good is to always pour Himself out - we learn something about who we really are as well. (Мы видим, что действия и личность Христа одно и то же. Когда мы видим, что природа Христа крестообразна, что опьяняющая радость Бога - всегда изливать Себя, мы узнаем также, кто мы есть на самом деле)" [Por. Crowder 2014, 19]. 
złego Boga Starego Testamentu - małego, zazdrosnego bożka ${ }^{24}$ od Chrystusa, którego z kolei sprowadza do rangi cierpiętnika, dzielącego wraz z człowiekiem okrutny los zgotowany przez mściwego Jehowę: „Распятие, его смысл. 1. Жертва для утишения гнева Иагве” [Поплавский 2009j, 287]. W momentach szczególnego załamania poeta wątpi również w miłość Jezusa, zastanawiając się nad tym, czy rzeczywiście jest tylko niewinną ofiarą Stwórcy, czy może raczej kłamcą, gdyż będąc synem Jahwe, musiał uczestniczyć w procesie kreacji, który, jak pamiętamy, Popławski uważał za źródło zła. Jego wątpliwości wypowiada główny bohater powieści i kolejne alter ego - Апполон Безобразов:

Ребенок он, твой Христос. Он Отца не видел никогда. Ему его доброта Отца заслонила. Вот он и сказал: «Я и Отец одно» (...) Если одно, то Христос обманщик: Он мир творил, Он невинных убивал, Он крокодиловые слезы проливал, лицемеря с косой в руке. И его вина горше всех. Если же не одно, то не знал ничего о Боге, ибо много лучше Бога был. Почему Отец его и предал ${ }^{25}$ [Поплавский 1996, 372].

W obu przypadkach, o jakich mowa w przytoczonym cytacie, Chrystus pozbawiony zostaje swojej prawdziwej natury. Jawi się jako okrutny demiurg, udający przyjaciela ludzi, bądź jako bezgranicznie dobra, ale bezwolna, słaba, strachliwa istota ${ }^{26}$, nie znająca pojęcia szczęścia ${ }^{27}$,

24 Oleg - główny bohater powieści Домой с небес i alter-ego Popławskiego mówi o Bogu w sposób następujący: „Олег чувствовал, что Бог боится его, ужасается его храбрости и любит его таким, как сейчас, совсем другой, страстной и страшной, любовью, а не покровительственной и мирной, которою он любил Олега женатого, бородатого, примиренного с жизнью, добродушно-молчаливого, безопасного. Нет, Бог снова любил в нем храбреца, девственника, аскета, пророка, Люцифера, как любит владыка красивейших, гордейших девушек племени, предначертав их для своего гарема, долго упорно борясь с их метафизической строптивостью. Он чувствовал грозное, напряженное, как сталь, облако божественной ревности над собою, преследующее его, как Израиль в пустыне. Как лебедь преследовал Леду, как бык ластился к Европе, как золотая туча спускалась к Данае" [Поплавский 2009b, 419].

25 Б. Поплавский, Апполон Безобразов. Первый вариант финала, [w:] Б. Поплавский, Неизданное: Дневники, статьи, стихи, письма, сост. и коммент. А. Богословского и Е. Менегальдо, Москва 1996, с. 372.

26 „И чему Иисус, неученый, низкого происхождения, дрожащий от страха, водящийся с порочными, их научит? (...) У Иисуса же смиренные друзья, как и Он сам, растерянные, ругающиеся, ужасающиеся, путающиеся, но... - соблазн! - не стыдящиеся своих страданий, копающиеся в них (...) Друзья Иисуса (...) всегда побиваемы, ставлены в неловкое положение, прерываемы, лишаемы голоса, запугиваемы, и Сам Иисус такой же был часто" [Поплавский 2009s, 427].

27 „Ибо Он (Chrystus - E. S.) любит, но и Он не знает, что такое счастье, и Он не знает, чему научить тех, кто к Нему обращаются ... обливаясь слезами, только утешить ..." [Поплавский 2009c, 432]. 
której rola ogranicza się do współczucia. „Gnostycka pokusa” („Гностическое искушение" ) [Менегальдо 2007, 240] przywodzi poetę w ślepy zaułek. Stąd nie ma już wyjścia, a właściwie jest tylko jedno - śmierć, przy czym śmierć wieczna, bez nadziei na zmartwychwstanie, gdyż, jak przyznaje Menegaldo, Popławskiemu obca jest Tajemnica Krzyża [Zob. Meнегальдо 2007, 232]. Dostrzega w nim jedynie cierpienie, zapominając o tym, że jego konsekwencją i darem jest zbawienie. Łada Syrowatko zaś stwierdza:

Для него Благая Весть - не в том, что Бог воскрес, а в том, что умер, стал мертвым среди мертвых из любви-жалости к живым, чтобы живые могли любить и жалеть его. Смертью Бога человек бунтующий навсегда с ним примирен [Сыроватко 2004, 175].

Autor Флагов, podobnie jak jego ogołocony z boskości, uniżony i umęczony Chrystus, nie potrafił czerpać radości z życia, nie umiał się nim cieszyć: „Ничто, буквально ничто меня не радует” [Поплавский 2009s, 431]. Dlatego, analogicznie jak jego wielki poprzednik - piewca śmierci i bogoburca - Fiodor Sołogub, swoją nieodłączną towarzyszką i muzą uczynił właśnie śmierć, którą postrzegał jako wybawienie i szczęście:

Tыл с луньл мне говоришь о счастье.

Cиастье - смерть ${ }^{28}$

Pani z białą kosą nie przyniosła jednak pocieszenia żadnemu ze swoich wielbicieli. Pozbawiając się zasady i źródła życia, jaką jest Bóg, mogli już tylko na nią czekać. Wydaje się, że zarówno Popławski, jak i Sołogub [Сологуб 1997, 576] ostatecznie zdali sobie sprawę z tego, iż ich droga okazała się mylna. „Rosyjski Rimbaud” na rok przed śmiercią w swoim dzienniku zapisuje słowa zdające się to poświadczać:

Ты слишком поверил в медитацию, в железную лапу грубого деланья. Ты зазнался в Боге, и вот расплата - полная потеря жизни, и вдруг просыпающийся в сердце голос: «Пути без возврата». [Поплавский 2009s, 439]

Reasumując, Popławski stał się ofiarą własnych dążeń do świętości [Бepдяев 2010, 9], zaś jego „romans z Bogiem” przerodził się w „dramat z Bogiem”. Z kolei śmierć, którą wysławiał, tak mocno się z nim „zżyła”, że

28 Б. Поплавский, Мистическое рондо I (Флаги) [Поплавский 2009a, 190]. 
przyszła zdecydowanie za wcześnie, przybierając postać narkotycznego snu, błogiego snu, o jakim marzył:

Спать. Уснуть. Как страшно одиноким.

Я не в силах. Отхожу во сньи.

Оставляю этот мир жестоким,

Ярким, жадныцм, грубьцм, остальныцмм ${ }^{29}$

\section{Literatura}

Crowder J., 2014, Still drunk on the gospel, tłum. С. Астапова, „The Ecstatic Magazine", spring-summer.

Cymborska-Leboda M., 2014, Русский православный «модернизм»: Николай Бердяев в споре об «ортодоксии», ереси и христианской вселенскости, „Slavia Orientalis” nr 4, s. 497-511.

Czarnecki R., Mistycy - wyrzutki realnego świata, [online], http://www.racjonalista. $\mathrm{pl} / \mathrm{kk} \cdot \mathrm{php} / \mathrm{s}, 3937 / \mathrm{k}, 3$ [06.04.2015].

Ginter G., Prawdziwie chrześcijańska modlitwa, [online], http://www.odnowa.jezu ici.pl/ [05.04.2015].

Kłoczowski J. A., 2003, Drogi człowieka mistycznego, Kraków.

Scriabine A., 1979, Notes et réflexions, Carnets inédits, Klincksieck. Cyt. za: B. Lassauzet, Faute de Mystère, il reste l'extase, [w:] Renaissances du Mystère en Europe fin XIX ${ }^{e}$ siècle - début XXI $I^{e}$ siècle, Strasbourg 2015.

Szkodoń J., 2003, Odpowiedzi na 101 pytań o duchowość w życiu codziennym, Kraków.

Tanquerey A., 2003, Zarys teologii ascetycznej i mistycznej, t. 1, tłum. P. Mańkowski, Warszawa.

Бердяев Н., 1926, Спасение и творчество (два понимания христианства), „Путь” № 2, с. 26-46.

Бердяев Н., 1932, Два понимания христианства (к спорам о старом и новом в христианстве), „Путь” № 36, с. 17-43.

Бердяев Н., 2010, По поводу «Дневников» Б. Поплавского, [w:] Б. Поплавский, Метафизический граммофон, Санкт-Петербург.

Варшавский В., 1993, Монпарнасские разговоры, [в:] Борис Поплавский в оценках и воспоминаниях современников, сост. Л. Аллен, О. Гриз, Санкт-Петербург.

Макгинн Б., Мистический союз в иудаизме, христианстве и исламе, [online], http://old.drugie.ru/page/1/3916/reading/ [25.04.2015].

29 Б. Поплавский, Il neige sur la ville [Поплавский 2009a, 268]. 
Менегальдо Е., 2007, Поэтическая вселенная Бориса Поплавского, СанктПетербург.

Мережковский Д., М. Ю. Лермонтов. Поэт сверхчеловечества, [online], lermontov.rhga.ru/upload/iblock/61b/24_Merezhkovs... [23.04.2015].

Поплавский Б., 1996, Апполон Безобразов. Первый вариант финала, [w:] Б. Поплавский, Неизданное: Дневники, статьи, стихи, письма, сост. и коммент. А. Богословского и Е. Менегальдо, Москва.

Поплавский Б. 2009а, Собрание сочинений в трех томах. Стихотворения, т. 1, Москва.

Поплавский Б., 2009b, Домой с небес, [w:] Б. Поплавский, Собрание сочинений в трех томах. Проза. Апполон Безобразов. Домой с небес, т. 2, Москва.

Поплавский Б., 2009c, Из дневников. 1928-1935, [w:] Б. Поплавский, Собрание сочинений в трех томах. Статьи. Днневники. Письма, т. 3, Москва.

Поплавский Б., 2009d, Рещензия на Путь. № 24 и 25 YMCA-Press. Париж, [w:] Б. Поплавский, Собрание сочинений в трех томах. Статьи. Днневники. Писвма, т. $3, \ldots$.

Поплавский Б., 2009е, Дневник. 1921-1922. Константинополь - Париж, [w:] Б. Поплавский, Собрание сочинений в трех томах. Статьи. Днневники. Письма, т. $3, \ldots$.

Поплавский Б., 2009f, Человек и его знакомьее, [w:] Б. Поплавский, Собрание сочинений в трех томах. Статьи. Дневники. Письма, т. $3, \ldots$.

Поплавский Б., 2009g, Из дневника. 1932. Париж, [w:] Б. Поплавский, Собрание сочинений в трех томах. Статьи. Днневники. Письма, т. $3, \ldots$.

Поплавский Б., 2009h, Письмо мокрое от слез, [w:] Б. Поплавский, Собрание сочинений в трех томах. Статьи. Днневники. Письма, т. $3, \ldots$.

Поплавский Б., 2009i, Из дневника. 1933. Париж, [w:] Б. Поплавский, Собрание сочинений в трех томах. Статьи. Днневники. Письма, т. 3, ... .

Поплавский Б., 2009j, Из дневника. 1929-1931. Париж, [w:] Б. Поплавский, Собрание сочинений в трех томах. Статьи. Днневники. Письма, т. $3, \ldots$. .

Поплавский Б., 2009k, Письма И. М. Зданевичу (4), [w:] Б. Поплавский, Собрание сочинений в трех томах. Статьи. Днневники. Письма, , т. 3, ... .

Поплавский Б., Дневник 1927 (публ. и коммент. Е. Менегальдо), „Новый Журнал” 2011, № 263, [online], http://magazines.russ.ru/nj/2011/263/po14-pr. html [18.08.2014].

Сологуб Ф., 1997, Как я с Тобой ни спорил, Боже, [w:] М. Павлова, Неизданный Федор Сологуб: стихи, документы, мемуары, Москва.

Сыроватко Л. В., 2004, Самоистязание двух видов («новое христианство» Бориса Поплавского), [w:] Русское зарубежье: приглашение к диалогу. Сборник научных трудов, ответственный ред. Л. В. Сыроватко, Калининград.

Татищев Н., 1993, О Поплавском, [в:] Борис Поплавский в оценках и воспоминаниях современников, сост. Л. Аллен, О. Гриз, Санкт-Петербург. 
Токарев Д., 2011, «Между Индией и Гегелем». Творчество Бориса Поплавского в компаративной перспективе, Москва.

THE POET'S DRAMA - BORIS POPLAVSKIJ'S "STRUGGLING WITH GOD"

S U M M A R Y

The foregoing article constitutes an attempt at analyzing the principal idea of Boris Poplavskij's artistic output, i.e. the so-called "romance with God". The subject of our scientific investigations is mainly the contents of that talented poet's diaries, as well as of his critical articles and letters, on the basis of which we tried to outline the spiritual silhouette of the author of Флагu (Flags), showing his attitude to God and religion.

Analysis of the listed sources revealed the poet's internal - spiritual and existential drama, mainly resulting from his religious syncretism (the Orthodox faith, esotericism, mysticism). It was established that the writer, after his Gnostic mentors, rejects the principle of the good God, who, in his consciousness undergoes a sort of involution - transferring from the object of desire into a bad demiurge, responsible for the evil and its spreading around the world. 